\title{
Isospora vanriperorum LEVINE, 1982 (APICOMPLEXA: EIMERIIDAE) IN THE GREEN-WINGED SALTATOR, Saltator similis LAFRESNAYE AND D'ORBIGNY, 1837 (PASSERIFORMES: CARDINALINAE) IN SOUTHEASTERN BRAZIL*
}

\author{
BRUNO DO B. LOPES ${ }^{1}$; BRUNO P. BERTO ${ }^{2}$; FABIANA V. MASSAD ${ }^{3 ;}$ CARLOS WILSON G. LOPES $^{4}$
}

\begin{abstract}
LOPES, B. DO B.; BERTO, B.P.; MASSAD, F.V.; LOPES, C.W.G. Isospora vanriperorum Levine, 1982 (Apicomplexa: Eimeriidae) in the green-winged saltator, Saltator similis (Passeriformes: Cardinalinae) in southeastern Brazil. [Isospora vanriperorum Levine, 1982 (Apicomplexa: Eimeriidae) no Trinca-ferro Saltator similis Lafresnaye and D'orbigny, 1837 (Passeriformes: Cardinalinae) no sudeste do Brasil]. Revista Brasileira de Parasitologia Veterinária, v. 16, n. 4, p. 211-214, 2007. Departamento de Parasitologia Animal, Instituto de Veterinária, Universidade Federal Rural do Rio de Janeiro, Km 7 da BR 465, Seropédica, RJ 23.890-000, Brasil. Email: lopescwg@ufrrj.br

Isospora vanriperorum from the green-winged saltator (Saltator similis) is described in Southeastern Brazil. Oocysts are spherical to subspherical, $19.4-26$ by $18.3-26 \mu \mathrm{m}(23.1$ by $22.4 \mu \mathrm{m})$, shape index 1.04 with a single layered wall, fine, smooth and yellowish. Micropyle and residuum are absents, but one elliptical polar granule is present. Sporocysts are ovoid, $14.5-20.2$ by $8.1-12.5 \mu \mathrm{m}(16.3$ by $10.8 \mu \mathrm{m})$, shape index 1.53 with prominent Stieda body, barely discernible substieda body and residuum centered and granulated.
\end{abstract}

KEY WORDS: Isospora vanriperorum, oocysts, green-winged saltator, Saltator similis

\section{RESUMO}

Isospora vanriperorum de trinca-ferro verdadeiro (Saltator similis) é descrita no sudeste do Brasil. Os oocistos são esféricos a subesféricos medindo $19,4-26$ por $18,3-26 \mu \mathrm{m}(23,1$ por $22,4 \mu \mathrm{m})$, índice morfométrico de 1,04 com parede única, fina, lisa e amarelada. A micrópila e o resíduo estão ausentes, mas um grânulo polar elíptico está presente. Os esporocistos são ovóides medindo $14,5-20,2$ por $8,1-12,5 \mu \mathrm{m}$ ( 16,3 por $10,8 \mu \mathrm{m})$, índice morfométrico de 1,53 com corpo de Stieda proeminente, corpo de substieda mal discernível e resíduo central e granular.

\footnotetext{
*Sob os auspícios do CNPq.

${ }^{1}$ Curso de Graduação em Biologia. Universidade Estácio de Sá. Vargem Grande, Rio de Janeiro. Estrada Boca do Mato, 850 - Vargem Pequena Rio de Janeiro CEP: 22783-320, Brazil. E-mail: brunolopesbio@oi.com.br

${ }^{2}$ Curso de Pós-Graduação em Microbiologia Veterinária. Universidade Federal Rural do Rio de Janeiro (UFRRJ). BR-465 km 07. Seropédica, RJ. CEP.: 23890-000, Brazil. E.mail: bertobp@ufrrj.br

${ }^{3}$ Curso de Pós-Graduação em Ciências Veterinárias. UFRRJ. BR-465 $\mathrm{km}$ 07. Seropédica, RJ. CEP.: 23890-000, Brazil. E.mail: fvmassad@yahoo.com.br - bolsista da CAPES

${ }^{4}$ Departamento de Parasitologia Animal. Instituto de Veterinária, UFRRJ. BR-465 km 07. Seropédica, RJ. CEP.: 23890-000, Brazil. E.mail: lopescwg@ufrrj.br - bolsista do CNPq
}

PALAVRAS-CHAVE: Isospora vanriperorum, oocistos, trinca-ferro verdadeiro, Saltator similis.

\section{INTRODUCTION}

The green-winged saltator Saltator similis Lafresnaye and D'Orbigny, 1837 is a native bird of South America. This species has a large range, with an estimated global extent of occurrence of $3,100,000 \mathrm{~km}^{2}$. Its global distribution is limited to the countries of Argentina, Brazil, Bolivia, Paraguay and Uruguay. In Brazil, it is occurs from Bahia to Rio Grande do Sul (BIRD LIFE INTERNATIONAL, 2004; LOUSADA et al., 2007).

Coccidiosis associated with genus Isospora in birds of the Emberizidae family, buntings and sparrows, was reported since Labeé (1896), where Isospora oocysts were described how the yellowhammer, Emberiza citrinella (DUSZYNSKI; COUCH, 2004).

Isospora vanriperorum was primarily described in northern cardinal, Cardinalis cardinalis, in Hawaii by Levine et al. (1980). The aim of this paper is to report and describe the sporulated oocysts of $I$. vanriperorum from the green-winged saltator, S. similis from Southeastern Brazil. 


\section{MATERIAL AND METHODS}

Samples. Fecal samples were collected from a cage bird, green-winged saltator, at the west zone in the City of Rio de Janeiro, Brazil. They were placed into plastic vials containing potassium dichromate solution $\left(\mathrm{K}_{2} \mathrm{Cr}_{2} \mathrm{O}_{7}\right)$ at $2.5 \% 1: 6 \mathrm{v} / \mathrm{v}$ and transported to the Laboratório de Coccídios e Coccidioses at Projeto Sanidade Animal (Embrapa/UFRRJ), Departamento de Parasitologia Animal, Instituto de Veterinária da Universidade Federal Rural do Rio de Janeiro. To induce sporulation, the fecal material was filtrated with double gauze and placed on Petri dishes at room temperature $\left(23-28^{\circ} \mathrm{C}\right)$ for ten days, until most oocysts are sporulated. Oocysts were recovered from the fecal samples by using saturated sugar flotation technique according Duszinsky and Wilber (1997).

Morphology. Morphological observations and measurements were performed by using a binocular microscope Carl Zeiss with apochromatic oil immersion objective and ocular micrometer K-15X PZO (Poland). Line drawings were prepared with a binocular microscope Wild M-20 with drawing tube.

Photographies. Pictures were prepared by using a digital camera model CD Mavica MVC-CD250 Sony ${ }^{\circledR}$.

\section{RESULTS}

Isospora vanriperorum Levine, 1982

Morphology. Oocysts (Figures 1and 2) are spherical to subspherical, $19.4-26$ by $18.3-26 \mu \mathrm{m}(23.1$ by $22.4 \mu \mathrm{m})$, shape index 1.04, with a single layered wall, fine, smooth and

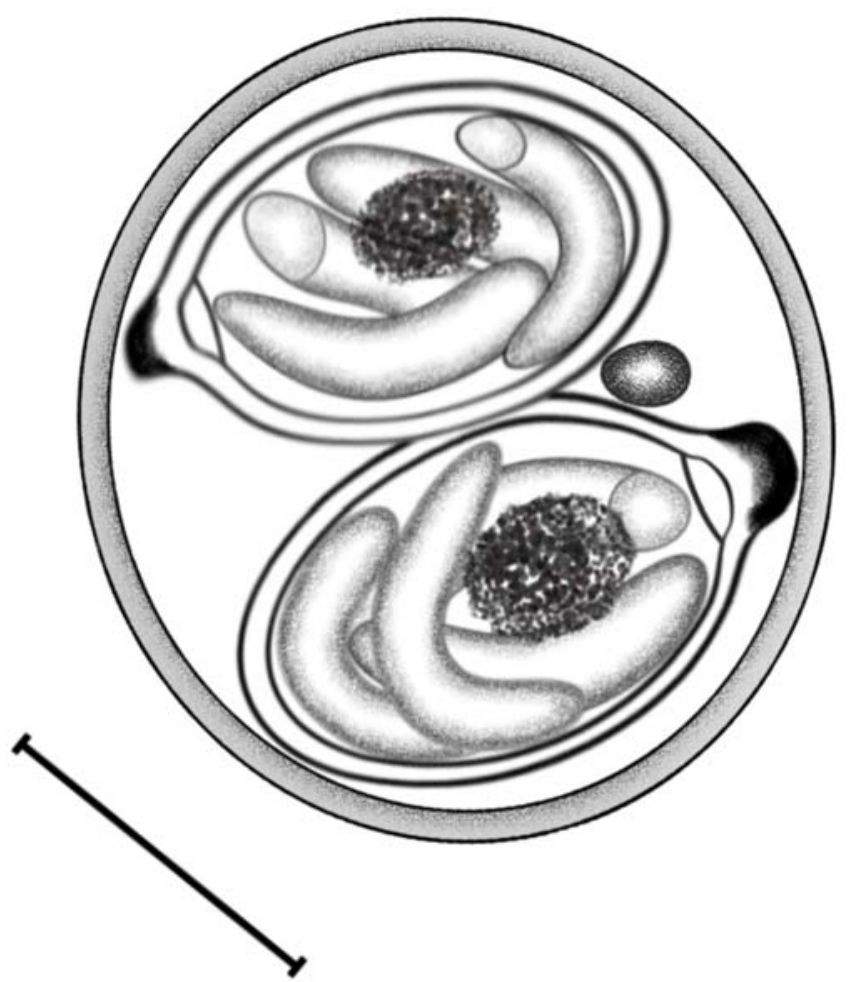

Figure 1. Isospora vanriperorum from Saltator similes. Sporulated oocyst. Line draw. $(-=10 \mu \mathrm{m})$

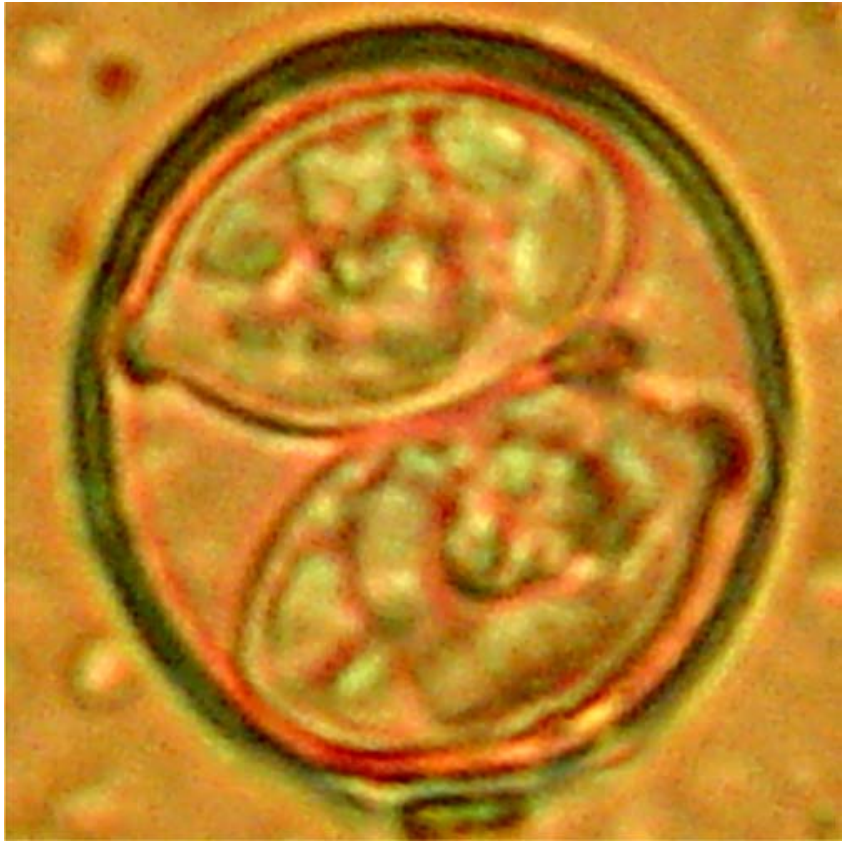

Figure 2. Isospora vanriperorum from Saltator similes. Sporulated oocyst. Saturated sugar solution. 1000X.

yellowish. Micropyle and residuum are absents, but one elliptical polar granule is present. Sporocysts are ovoid, 14.520.2 by $8.1-12.5 \mu \mathrm{m}$ ( 16.3 by $10.8 \mu \mathrm{m})$, shape index 1.53 , with prominent Stieda body, barely discernible Substieda body and residuum centered and granulated.

\section{Taxonomic summary}

Host: The green-winged saltator, Saltator similis (Passeriformes: Emberizidae: Cardinalinae).

Site of infection: not investigated.

Locality: City of Rio de Janeiro, Brazil.

Geographic distribution of the host: since the central region of Brazil until the southwest of South America.

Type material and specimens deposited: oocysts in 10\% formaldehyde-saline solution deposited at the Parasitology Collection, in the Department of Animal Parasitology, UFRRJ, Seropédica, State of Rio de Janeiro, Brazil. Repository number is $06 / 2006$, including phototypes and line drawings.

Disease: None reported.

\section{DISCUSSION}

According to the data presented above the oocysts found in the green-winged saltator, S. similis, belongs to the species of $I$. vanriperorum. This species was originally described as I. cardinalis by Levine et al. (1980), with others new species: I. brayi, I. ivensae, I. loxopis and I. phaernis. However, as this name was preoccupied for Gottschalk (1972), it was later renamed by Levine (1982) as I. vanriperorum.

Numerous coccidia have been described from birds of Emberizidae family. Isospora emberizae (MANDAL; CHAKRAVARTY,1964), whose host Emberiza bruniceps 
(Red-headed bunting) (Emberezidae: Emberezinae) is distributed in Asia and Europe, I. exigua, I. fragmenta, I. rotunda, I. temeraria (MCQUISTION; WILSON, 1988), whose host Camarhynchus parvulus (Small tree finch) (Emberezidae: Emberezinae) is observed in Galapagos Islands, and I. geospizae (MCQUISTION; WILSON, 1989) and I. daphnensis (MCQUISTION, 1990), whose host Geospiza fortis (Medium-ground finch) (Emberezidae: Emberezinae) is also observed in Galapagos Islands, inhabit South America. Theses species meet in geographic isolation disabling the hypothesis of cross transmission.

In the American continent, 10 species of Isospora were described in birds simpatric with Saltator similis of Emberizidae family: I. paroariae reported by Upton et al. (1985) from the red-crested cardinal, Paroaria coronata (Emberezidae: Emberezinae), differs from the oocysts described in this paper because of a bi-layered wall and no polar granule.

McQuistion and Capparella (1992) described I. pityli and I. formarum from slate-colored grosbeak Saltator grossus (= Pitylus grossus) (Emberezidae: Cardinalinae) in Ecuador. Isospora pityli differs completely, therefore the oocysts are smaller $(20-20.5$ by $17-20 \mu \mathrm{m})$, presents bi-layered wall and no polar granule and substieda body are observed. Isospora formarum is different by presenting bi-layered wall, the substieda body is larger and triangular and no presents polar granule.

Isospora tiaris by Ball and Daszak (1997), was described from soot grassquit, Tiaris fuliginosa (Emberezidae: Emberezinae) in Venezuela. Oocysts (20-20.5 by $17-20 \mu \mathrm{m})$ are smaller than those described in this paper and present bilayered wall.

Carvalho Filho et al. (2005), identified three new species from the double-collared seed eater, Sporophila caurelescens (Emberezidae: Emberezinae), from Eastern Brazil: Isospora sporophilae, I. flausinoi and I. teixeirafilhoi. First of all, these three species differ by having bi-layered wall and no present substieda body and, in second; the diameters of oocysts of the I. flausinoi (14-20.00 by $13.60-20.00)$ and I. teixeirafilhoi (15.60-19.40 by $14.20-18.80)$ are smaller.

Recently, Silva et al. (2006) identified three new species from the lesser seed-finch Oryzoborus angolensis from Brazil. Isospora curio and I. braziliensis. Both do not have a polar granule and substieda body; however I. paranaensis of the same host had a similar morphology with the oocysts described in this paper, excepted the substieda body which is large and prominent in the I. paranaensis sporocysts, while in the sporocysts described in this paper were barely discernible.

Descriptions of Isospora species in subfamily Cardinalinae, where C. cardinalis and S. similis, are inserted and scarce. Beyond Levine et al. (1980) and this paper that described $I$. vanriperorum in Brazil, only McQuistion and Capparella (1992) have described two others species, I. pityli and I. formarum from the slate-colored grosbeak, $P$. grossus in Ecuador.

\section{REFERENCES}

BALL, S. J.; DASZAK, P. Isospora tiaris n. sp. (Apicomplexa: Eimeriidae) from the sooty grassquit (Tiaris fuliginosa), a passeriform bird of South America. American Society of Parasitologists, v. 83, n. 3, p. 465-466, 1997.

BIRD LIFE INTERNATIONAL, 2004. Saltator similis. In: IUCN 2006. Red list of Threatened Species. Available on: $<$ http://www.iucnredlist.org>. Access: Mar 21, 2007.

CARVALHO FILHO, P.R. DE; MEIRELES, G.S.; RIBEIRO, C.T.; LOPES, C.W.G. Three new species of Isospora Schneider, 1881 (Apicomplexa: Eimeriidae) from the double-collared seed eater, Sporophila caerulescens (Passeriformes: Emberizidae), from Eastern Brazil. Memórias do Instituto Oswaldo Cruz, v. 100, n. 2, p. 151-154, 2005.

DUSZYNSKI, D. W.; COUCH, L. The coccidia of Passeriformes (Isospora), 2004. Available on: <http:// www.k-state.edu/parasitology/worldcoccidia $>$. Access: Mar 21, 2007.

DUSZYNSKI, D. W.; WILBER, P. G. A guideline for the preparation of species descriptions in the Eimeriidae. Journal of Parasitology, v. 83, n. 2, p. 333-336, 1997.

GOTTSCHALK, C. Beitrag zür Faunistik der Vogelkokzidien Thuringens und Sachsens. Betrage zür Vogelkunde, v. 18, n. 1, p. 61-69, 1972.

LABBÉ, A. Recherches zoologiques, cytologiques et biologiques sur less coccidies. Archives de Zoologie Experimentale et Generale, v. 24, n. 3, p. 517-654, 1896.

LEVINE, N.D. Isospora vanriperorum n. nom. for I. cardinalis Levine, Van Riper \& Van Riper, 1980, preoccupied. Journal of Protozoology, v. 29, n. 4, p. 653, 1982.

LEVINE, N.D.; VAN RIPER, S.; VAN RIPER, C. Five New Species of Isospora from Hawaiian Birds. Journal of Protozoology, v. 27, n. 3, p. 258-259, 1980.

LOUSADA, E.E.D.; FARIAS, S.P.; LASMAR, J.M.; MIRANDA, A.P. Trinca-Ferro Verdadeiro. Portal da Federação Ornitológica de Minas Gerais. Available on: $<$ http:/ /www.feomg.com.br>. Access: Mar 21, 2007.

MANDAL, A.K. AND CHAKRAVARTY, M.M. Studies on some aspects of avian coccidia [Protozoa: Sporozoa]. 2. Five new species of Isospora Schneider, 1881. Proceedings of the Zoological Society, v. 17, p. 35-45, 1964.

MCQUISTION, T.E. Isospora daphnensis n. $\mathrm{sp}$. (Apicomplexa: Eimeriidae) from the medium ground finch (Geospiza fortis) from the Galapagos Island. Journal of Parasitology, v. 76, n. 1, p. 30-32, 1990.

MCQUISTION, T.E.; CAPPARELLA, A. Two new coccidian parasites from the slate-colored grosbeak (Pitylus grossus) of South America. Journal of Parasitology, v. 78, n. 5, p. 805-807, 1992.

MCQUISTION, T.E.; WILSON, M. Four new species of Isospora from the small tree finch (Camarhynchus parvulus) from the Galapagos Island. Journal of Protozoology, v.35, n. 1, p. 98-99, 1988. 
MCQUISTION, T.E.; WILSON, M. Isospora geospizae, a new coccidian parasite (Apicomplexa: Eimeriidae) from the small ground finch (Geospiza fuliginosa) and the medium ground finch (Geospiza fortis) from the Galapagos Island. Systematic Parasitology, v. 14, n. 2, p. 141-144, 1989.

SILVA, E.A.T DA; LITERÁK, I; KOUDELA, B. Three new species of Isospora Schneider, 1881 (Apicomplexa:
Eimeriidae) from the lesser seed-fich, Oryzoborus angolensis (Passeriformes: Emberizidae) from Brazil. Memórias do Instituto Oswaldo Cruz, v. 101, n. 5, p.573576, 2006.

UPTON, S.J.; CURRENT, W.L.; CLUBB, S.L. Two new species of Isospora (Apicomplexa: Eimeriidae) from passeriform birds of South America. Systematic Parasitology, v. 7, n. 3, p. 227-229, 1985.

Received on May 16, 2007.

Accepted for publication on September 21, 2007. 